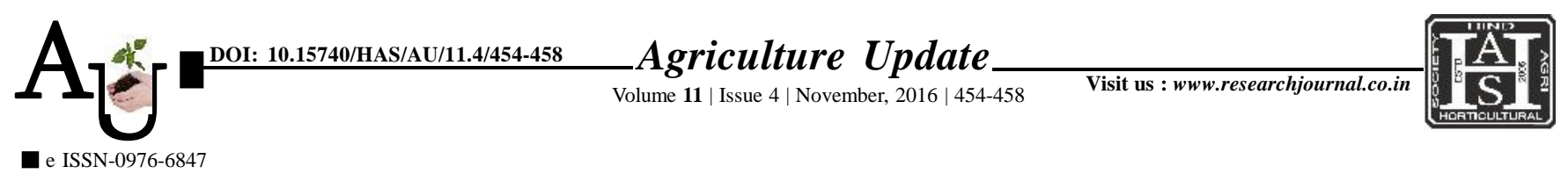

\title{
A Case Study : \\ Unique technique of finger millet production under SRI system for higher yield potential in eastern India
}

\author{
M.K. SINGH, S.K. GUPTA AND S.K. CHOUDHARY
}

Article Chronicle:

Received :

26.05.2016;

Accepted :

25.10.2016

KeY Words:

Unique technique,

Finger millet

production, SRI,

Higher yield

potential

SUMMARY : Finger millet is a staple food crop in dryland, tribal areas and Diayara areas. It is cultivated both for grains and 'fodder. SRI principles have been creatively adopted to suit the cultivation practices for finger millet, making it possible to produce 3-4 times more crop yield than with farmers' traditional practices, without depending on new varieties. It does use small amounts of purchased inputs along with mostly organic inputs. It is cultivated mainly in Asia and Africa. It is staple food crop in many hilly regions of the country and it is grown both for grain and forage. In Northern hills, grains are eaten in the form of chapaties and in South India, grain flour is used for preparing gruel, cakes or unleavened bread, puddings, porridges, sweets etc. Germinating grains are malted and fed to infants and good for pregnant woman. It is considered as nutritive food for adults of different ages. Grains contain 9.2 per cent protein, 1.29 per cent fat, 76.32 per cent carbohydrates, 2.24 per cent minerals 3 per cent ash and 0.33 per cent $\mathrm{Ca}$. It also contains vitamins A and B with small amount of P. It is good for persons suffering from diabetes. Green straw is suitable for making silage.

How to cite this article : Singh, M.K., Gupta, S.K. and Choudhary, S.K. (2016). Unique technique of finger millet production under SRI system for higher yield potential in eastern India. Agric. Update, 11(4): 454-458; DOI : 10.15740/HAS/AU/11.4/454-458.

Author for correspondence :

\section{M.K. SINGH}

Department of

Agronomy, Bihar Agricultural University,

Sabour, BHAGALPUR (BIHAR) INDIA

See end of the article for authors' affiliations 